
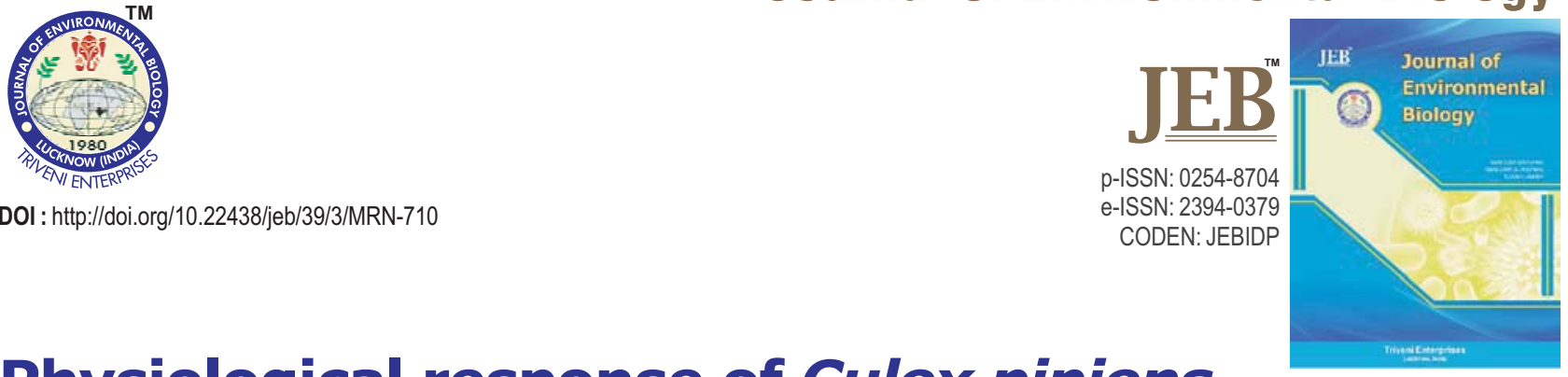

\title{
Physiological response of Culex pipiens larvae to sublethal concentrations of sodium and calcium hypochlorite
}

Authors Info

Z. Shu', M. Shahen ${ }^{1,2 *}$, M.A.M. Hegazi $^{2}$, I.M. Al-Sharkaw ${ }^{2}$ and A.I. Seif ${ }^{2}$

${ }^{1}$ College of Life Science, Northwest A \& F University, Yangling, Shaanxi, 712 100, China ${ }^{2} Z$ Zoology Department, Faculty of Science, Tanta University Tanta, 31527, Egypt

*Corresponding Author Email : Mshahen@science.tanta.edu.eg

\section{Key words}

Acetylcholinesterase Culex pipiens

Histopathological changes

Physiological response

Sodium hypochlorite

\section{Publication Info}

Paper received : 03.08.2017

Revised received : 10.10.2017

Re-revised received : 24.11.2017

Accepted :28.11.2017

\section{Abstract}

Aim : The present study investigated the physiological responses and histopathological changes of Culex pipiens larvae exposed to sublethal concentrations of sodium and calcium hypochlorite.

Methodology : The concentration of total protein, lipids and carbohydrates as well as activity of acetylcholinesterase were determined in larvae using colorimetric methods. The interaction between hypochlorite and fourth instars larvae of $C$. pipiens was followed through histological sections.

Results : The contents of total protein and total carbohydrates of all larval instars increased following treatment with sublethal concentrations of both hypochlorite compounds. However, treatment of larvae with $1 / 10 \mathrm{LC}_{50}$ induced significant reduction in the total carbohydrate content. In addition, treatment of larvae with sublethal concentrations of both hypochlorite compounds induced significant reduction in the total lipid content. Furthermore, the acetylcholinesterase activity significantly decreased in treated first and second larval instars, while increased in treated third and fourth larval instars.

Interpretation : In larvae treated with sublethal concentrations of calcium and sodium hypochlorite, the mid gut cells appeared thinner and flattened, with disappearance of the peritrophic matrix and reduced fat body. The present study suggested that hypochlorite compounds had a pronounced effect on larval metabolic pathways.

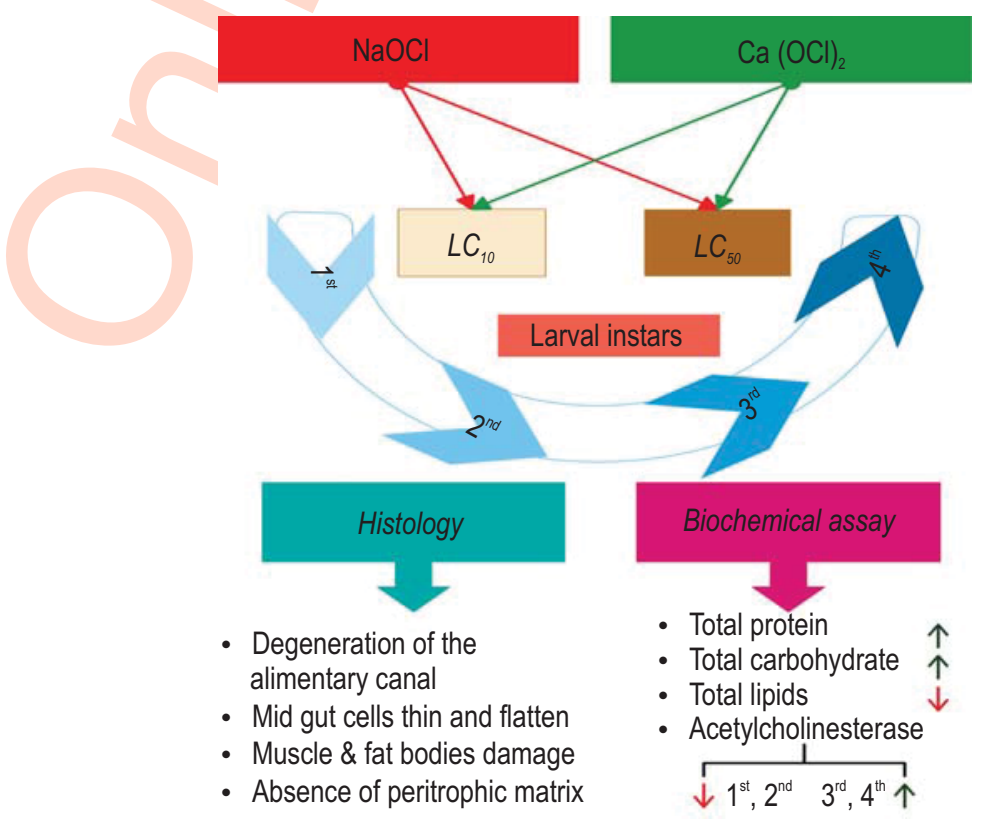




\section{Introduction}

Mosquito-borne diseases are an increasing cause of death and suffering in almost all tropical and subtropical countries (Andersen and Davis, 2016; Fouad et al., 2017). They are responsible for the transmission of the pathogens causing debilitating diseases of man like malaria and some of the most life-threatening like lymph node filariasis, dengue fever, yellow fever, Japanese encephalitis and others (Tangena et al., 2016; Brustolin et al., 2017). Mosquitoes are major disease vectors as well as nuisance insects, and therefore are relevant to control programs in Egypt. Among these mosquito species, Culex pipiens (C. pipiens) complex has been reported as the major vector of bancroftian filariasis (Southgate, 1979) and viral diseases in Egypt (Korte et al., 2013; Al-Mekhlafi et al., 2017). C. pipiens is common and widely distributed species across the Egypt (Cabrerizo Ballesteros et al., 2006).

Insects may survive the impact of toxic chemical compounds by different techniques including detoxifying enzyme production and target site sensitivity. Mosquitoe fat body is performed by cells to the body wall of thorax and abdomen, prolongating itself in the body cavity and besetment specific organs (David et al., 2016; Chang et al., 2017). All carbohydrates and lipids found in the adult originated from the stored energy gained over the stage of larvae (Mitchell et al., 2015). (Huang et al., 2014; Rozsypal et al., 2014; Kim and Ahn, 2017) declared that avermectin could affect insect organs such as the fat body. For example, avermectin could act on the cell membranes of fat body of Culex quinqufasciaus protein uptake, carbohydrate, and inhibited lipid making with that these cytoplasmic inclusions become minors. Insecticide resistance in all insects are variations in changes in the rate or the target site at which the insecticide is detoxified (Raymond et al., 2001; Kim and Ahn, 2017).

Recently, monooxygenases, S- transferases, glutathione and esterases are recognized to be interested in the detoxification groups of insecticides (Labbe et al., 2007; Hayat et al., 2017). Physiological resistance to insecticides will be increased by activity of these enzymes (Roberts and Andre, 1993; Yadouleton et al., 2010). Multifunction oxidases and esterases are interested in the resistance to pyrethroids. Also acetylcholine esterase, responsible for neurotransmitter degradation at the cholinergic nerve synapse, is the target of both organophosphate and carbamate insecticides (Mutero et al., 1994). The resistance is mainly maintained by reduced sensitivity in acetylcholinesterase to insecticides (Djogbénou et al., 2010).

There are no reports on the effect of hypochlorite compounds on the activity/levels of enzymes and other macromolecules in C. pipiens. Therefore, the present study was planned to understand the biochemical effects of these compounds on C. pipiens, when exposed to sublethal concentration levels, which usually occur after field application of the compounds. Chlorinated lime has been largely used for the control of cercariae in irrigation canal and ditches in Egypt (AlSharkawi, 1997). Previous researches have shown that sodium hypochlorite was lethal for immature stages of mosquitoes. (Barrera et al., 2004) found that $100 \mathrm{ppm}$ of chlorine dosage killed Aedes aegypti in 24 hours in both pure and water from a larval habitat.

The aim of the present study was to determine histological and physiological changes of the tissues, the biochemical profile of the primary metabolites (total protein, total carbohydrates, and total lipids) and estimation of acetylcholinesterase activity in C. pipiens larvae after exposure to sub lethal concentrations of sodium and calcium hypochlorite.

\section{Materials and Methods}

Culex pipiens source and maintenance : C. pipiens was obtained from larval breeding site at Tanta city, Egypt. The collected larvae were transferred to a plastic whirl-pack bags (Nasco) half-filled with water from the breeding place and transferred to the laboratory. In the laboratory, fourth instar larvae were collected and identified using the proposed key of (Harbach, 1988) for Egyptian culicine mosquitoes.

The mosquito colony was maintained in the insectary room at $27-30^{\circ} \mathrm{C}$ and approximately $70 \%$ humidity in the animal house, Zoology Department, Faculty of Science, Tanta University, Egypt. All experiments were conducted on the $F_{1}$ generation of the field collected $4^{\text {th }}$ instar larvae.

Histological studies : The larvae were exposed to $1 / 10 \mathrm{LC}_{50}$ and $\mathrm{LC}_{50}$ of sodium and calcium hypochlorite for $24 \mathrm{~h}$. After that they were fixed in formalin (5\%) at room temperature for $24 \mathrm{~h}$. Sections were stained with Mayer's hematoxylin for 15 minutes, washed with distilled water or alkaline alcohols and counter stained with eosin for 20-60 min. After dehydration, sections were cleared in xylene for 10 min and mounted in Canada balsam for further examination.

Biochemical studies : The total lipids, proteins and carbohydrates as well as acetylcholinesterase activity were evaluated for each larval stage of C. pipiens that survived exposed to two different concentrations of $1 / 10 \mathrm{LC}_{50}$ and $L C_{50}$ values estimated for $1^{\text {st }}, 2^{\text {nd }}, 3^{\text {rd }}$ and $4^{\text {th }}$ larval instars. The experiment was conducted under the above-mentioned conditions.

Preparation of insect homogenates for the biochemical assays : Batches of eighty larvae at each stage of $C$. pipiens development exposed to the selected sub lethal concentrations of both hypochlorite compounds for $24 \mathrm{~h}$ were removed from the rearing pans and were used for the biochemical analysis. The larvae were homogenized in $10 \mathrm{ml}$ distilled water. Homogenates were centrifuged at $3000 \mathrm{~g}$ and $2^{\circ} \mathrm{C}$ for 10 . Supernatant was used directly for biochemical assays. 
Determination of total body protein content : The method described by (Lowry et al., 1951) was conducted to measure the total body protein content the intensity of the blue color resulted from reaction with Folin reagent was measured photometrically at $520 \mathrm{~nm}$. The concentration of protein was calculated using the following equation:

$$
\text { Total protein contents }=\frac{\mathrm{A}_{\text {Test }}}{\mathrm{A}_{\text {standard }}} \times \quad \mathrm{mg} \text { per larva }
$$

Determination of total body carbohydrate content: The colour reaction given by anthrone reagent was used for determination of total carbohydrate contents of mosquito larvae by spectrophotometric method (Singh and Sinha, 1977). The concentration of the carbohydrates $(\mathrm{mg} / \mathrm{ml})$ was plotted against the corresponding absorbance to draw the standard calibration curve, which was used further for carbohydrate determination in the mosquito homogenate and expressed as mg carbohydrates/larva.

Determination of total body lipid content : The total lipid content of larvae was determined using the method described by (Frings et al., 1972). The absorbance was measured at $540 \mathrm{~nm}$; the concentration of the total lipids was estimated by the following equation;

$$
\text { Total lipid contents }=\frac{\mathrm{A}_{\text {Test }}}{\mathrm{A}_{\text {Standard }}} \times \quad \mathrm{mg} \text { per larva }
$$

Determination of acetylcholinesterase activity : The activity of acetylcholinesterase in insect supernatant was determined following the method described by Ellman et al. (1961) using acetylthiocholine as a substrate. Measurements were conducted at a wavelength of $412 \mathrm{~nm}$. The activity of acetylcholinesterase (AChE) was calculated by the following equation;

$$
\begin{aligned}
& \text { AChE activity }=\frac{A_{\text {Test }}}{A_{\text {standard }}} \mu \mathrm{mol} \mathrm{SH} \quad X \frac{1}{30(\mathrm{~min})} \mu \mathrm{mol} \mathrm{SH} \\
& =\mu \mathrm{mol} \text { SH per min per larva }
\end{aligned}
$$

Statistical analysis : Results were presented as mean \pm standard deviation (SD) from six readings. The statistical analyses were carried out using SAS 6.2. Data obtained were analysed statistically to determine the degree of significance between treatments using one-way analysis of variance (ANOVA). Additionally, the LSD test was used to determine treatment differences comparing with the corresponding control at probability level $(P) \leq 0.01$.

\section{Results and Discussion}

Histological changes induced by exposure of $\mathrm{C}$. pipiens larvae to sub lethal concentrations of sodium and calcium hypochlorite.
In control mosquito larvae, the peritrophic membrane was always present forming endo- and ecto-peritrophic spaces, the mid gut exemplifies a single epithelium columnar cells with evident striated border (Fig. 1A). The treatment of $C$. pipiens larvae with sub lethal concentrations of sodium and calcium hypochlorite led to degeneration of cell structure of alimentary canal. In larvae treated with sub lethal concentrations of calcium and sodium hypochlorite, the mid gut cells appeared thinner and flattened with disappearance of the peritrophic matrix (Fig. 1B).

Control larvae showed well developed visceral and peripheral fat body cells with cytoplasm presenting considerable granulation following the standard patterns of other insects (Fig. 1A). However, larvae treated with sub lethal concentrations of hypochlorite showed reduced fat body (Fig. 1B). In the treated larvae, muscle change was also evident. In addition, the cuticle of body wall was thinner than that of control mosquitoes with attenuated hypodermal cells (Fig. 1C). In control larvae, the malpighian tubules were formed by cells with evident spherical nucleus and excretory products in the lumen (Fig. 1D). In larvae exposed to sub lethal concentrations of hypochlorite accumulation of any substances in its lumen was not observed, which was narrower than that of the control larvae (Fig. 1E). Hence, the treated larvae showed reduced fat body, muscle and malpighian changes. A survey of literatures failed to reveal studies in which the morphological and histological effects of hypochlorite compounds were elucidated. However, (Pu et al., 2010; Ferreira et al., 2017) data of the histological studies suggested that the reduced fat body tissues may be responsible for the drastic changes observed in the biochemical profiling of hypochlorite treated larvae.

Biochemical studies : Biochemical parameters of $C$. pipiens larval instars were assessed after exposure to $1 / 10 \mathrm{LC}_{50}$ and $\mathrm{LC}_{50}$ of sodium and calcium hypochlorite. In the present study, it is clear that hypochlorite compounds showed toxic effect on larval metabolic pathways. The two hypochlorite were selected because of their relatively high potency against mosquito larvae.

Total protein content : Table 1 shows the mean total body protein contents of different larval instars of $C$. pipiens exposed to sub lethal concentrations of sodium and calcium hypochlorite. In general, the total body protein of all larval instars increased after treatment with sub lethal concentrations of both sodium and calcium hypochlorite as compared with control. The total body protein content values of control $1^{\text {st }}, 2 \mathrm{nd}, 3^{\text {td }}$ and $4^{\text {th }}$ larval instars are shown in Fig. 2A. Treatment of larvae with $1 / 10 \mathrm{LC}_{50}$ of sodium hypochlorite significantly increased the total body protein contents as compared with control values. Similarly, larvae treated with sub lethal concentrations of sodium hypochlorite, the total body protein content values were significantly higher than those of the control. A similar trend was also observed when larvae were exposed to sub lethal concentrations of calcium hypochlorite. The total body protein content values of $1^{\text {st }}, 2^{\text {nd }}, 3^{\text {rd }}$ and $4^{\text {th }}$ larval instars treated with $1 / 10 \mathrm{LC}_{50}$ of calcium hypochlorite 

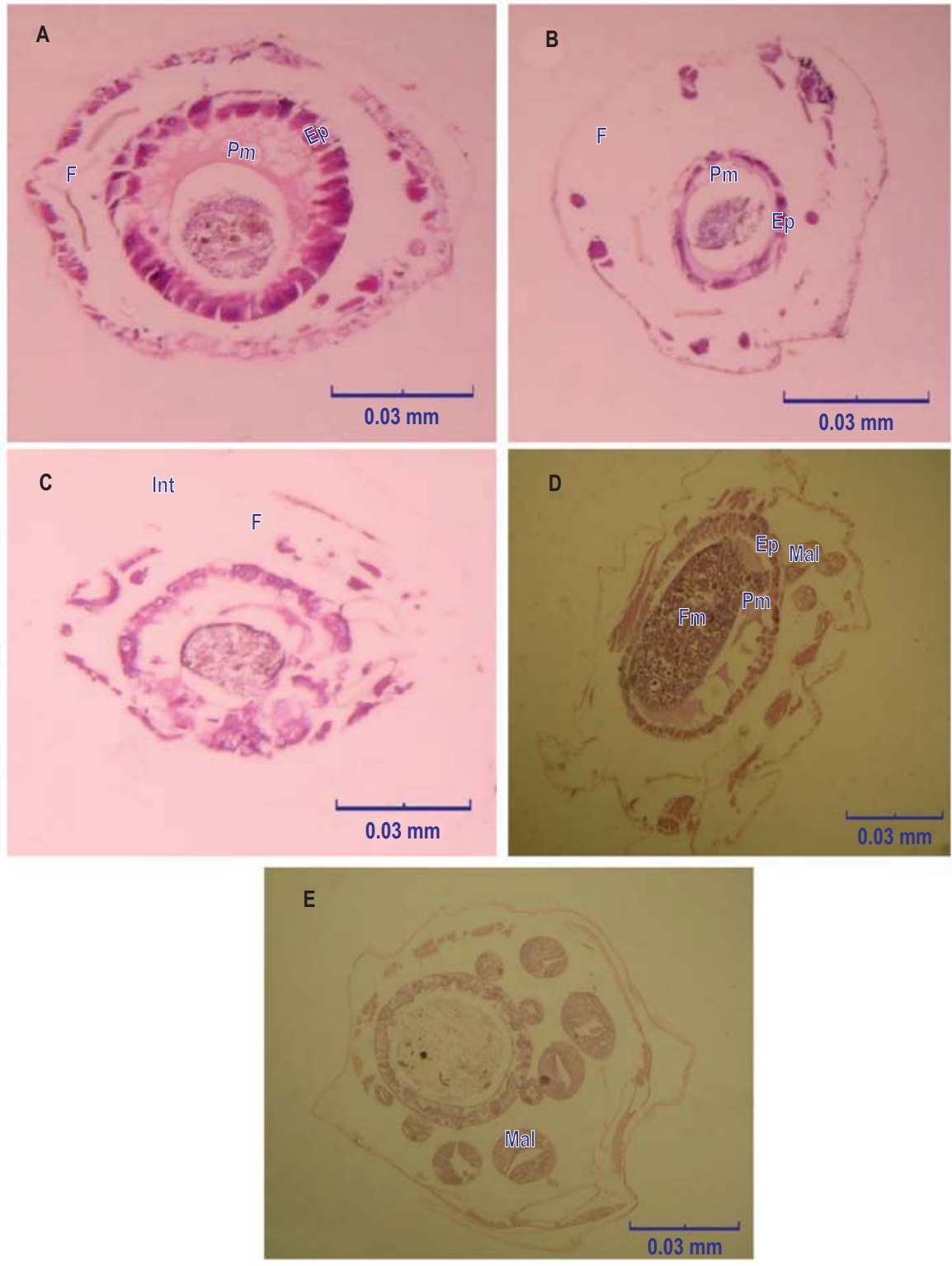

Fig. 1 : Cross section through C. pipiens $4^{\text {th }}$ instar larva : (A) In control larvae showing the mid gut with single columnar epithelial cells (Ep), the peritrophic membrane $(\mathrm{Pm})$, and developed peripheral fat body layer (F); (B) Larvae exposed to $\mathrm{LC}_{50}$ calcium hypochlorite. Notice degeneration of the mid gut cells which appear thinner and flattened (Ep), distortion of the peritrophic membrane (Pm), and disappearance of the fat body $(\mathrm{F}) ;(\mathrm{C}) \mathrm{Larvae}$ exposed to $\mathrm{LC}_{50}$ calcium hypochlorite. Note the distortion of the integument (Int) and reduced fat body layer (F); ( D) Control larvae showing mid gut with single columnar epithelial cells $(\mathrm{Ep})$, the peritrophic membrane (Pm), food mass, (Fm), Malpighian tubules (Mal) with spherical nucleus and excretory products in the lumen and $(E)$ Larvae exposed to $L_{50}$ calcium hypochlorite. Notice that the accumulation of substances in Malpighian tubules lumen (Mal) was not observed

were significantly higher than that of control (Fig. 2B). Similarly, treatment of larvae with $\mathrm{LC}_{50}$ of calcium hypochlorite induced significant increase in the total body protein contents as compared with control.

The increase in protein content may indicate a physiological adaptation to compensate the insecticidal stress. Hemolymph volume changes under insecticide stress resulting in alteration in protein concentration (Neoliya et al., 2007). The increase in protein content might also be due to formation of lipoprotein, which can be used to repair damaged cells and tissue organelles. In the present study, histological examination of larvae exposed to sub lethal concentrations of both hypochlorite revealed considerable damage in the muscles and mid gut cells. However, no published data are available on the effect of hypochlorite compounds on the biochemical activity of larval 
Table 1 : Total body protein content of $C$. pipiens larval instars exposed to sublethal concentrations $\left(1 / 10\right.$ of $L_{50}$ and $\left.L_{50}\right)$ of sodium and calcium hypochlorite

\begin{tabular}{|c|c|c|c|c|c|}
\hline \multirow{3}{*}{$\begin{array}{l}\text { Larval } \\
\text { instars }\end{array}$} & \multicolumn{5}{|c|}{ Total body protein contents of larvae } \\
\hline & \multirow[t]{2}{*}{ Control } & \multicolumn{2}{|c|}{ Sodium hypochlorite } & \multicolumn{2}{|c|}{ Calcium hypochlorite } \\
\hline & & $1 / 10 \mathrm{LC}_{50}$ & $\mathrm{LC}_{50}$ & $1 / 10 L_{50}$ & $\mathrm{LC}_{50}$ \\
\hline $1^{\text {st }}$ & $6.67 \pm 0.59$ & $16.89 \pm 1.31^{*}$ & $23.389 \pm 0.31^{*}$ & $14.82 \pm 0.5^{*}$ & $22.31 \pm 0.75^{*}$ \\
\hline $2^{\text {nd }}$ & $16.99 \pm 0.55$ & $23.78 \pm 0.38^{*}$ & $24.38 \pm 0.36^{*}$ & $19.99 \pm 0.41^{*}$ & $23.81 \pm 0.39^{*}$ \\
\hline $3^{\text {rd }}$ & $21.57 \pm 0.17$ & $25.62 \pm 0.29^{*}$ & $27.96 \pm 0.55^{*}$ & $24.77 \pm 0.44^{*}$ & $25.73 \pm 0.48^{*}$ \\
\hline $4^{\text {th }}$ & $22.86 \pm 0.43$ & $28.09 \pm 0.31^{*}$ & $35.15 \pm 1.81^{*}$ & $28.25 \pm 0.26^{*}$ & $32.21 \pm 0.37^{*}$ \\
\hline
\end{tabular}

Values are mean of six replicates $\pm S D$; ${ }^{*}$ Significant at $P \leq 0.001$ using multi-way analysis of variance (ANOVA)

Table 2 : Total body carbohydrate contents of $C$. pipiens different larval instars exposed to $1 / 10 \mathrm{LC}_{50}$ and $\mathrm{LC}_{50}$ of sodium and calcium hypochlorite

\begin{tabular}{|c|c|c|c|c|c|}
\hline \multirow{3}{*}{$\begin{array}{l}\text { Larval } \\
\text { instars }\end{array}$} & \multicolumn{5}{|c|}{ Total body protein contents of larvae } \\
\hline & \multirow[t]{2}{*}{ Control } & \multicolumn{2}{|c|}{ Sodium hypochlorite } & \multicolumn{2}{|c|}{ Calcium hypochlorite } \\
\hline & & $1 / 10$ LC $_{50}$ & $\mathrm{LC}_{50}$ & $1 / 10 \mathrm{LC}_{50}$ & $\mathrm{LC}_{50}$ \\
\hline $1^{\text {st }}$ & $2.28 \pm 0.13$ & $1.60 \pm 0.07^{*}$ & $2.61 \pm 0.11^{*}$ & $1.90 \pm 0.13^{*}$ & $2.53 \pm 0.15^{\star}$ \\
\hline $2^{\text {nd }}$ & $6.71 \pm 0.77$ & $5.74 \pm 0.32^{*}$ & $12.28 \pm 0.81^{*}$ & $4.56 \pm 0.14^{*}$ & $11.14 \pm 0.80^{*}$ \\
\hline $3^{\text {rd }}$ & $11.64 \pm 0.95$ & $9.15 \pm 0.81^{*}$ & $18.14 \pm 0.78^{*}$ & $7.71 \pm 0.86^{*}$ & $13.74 \pm 0.38^{*}$ \\
\hline $4^{\text {th }}$ & $26.86 \pm 0.89$ & $25.34 \pm 2.14^{*}$ & $29.54 \pm 4.91^{*}$ & $26.16 \pm 0.99^{*}$ & $32.6 \pm 5.25^{\star}$ \\
\hline
\end{tabular}

Values are mean of six replicates $\pm S D$; ${ }^{*}$ Significant at $P \leq 0.001$ using multi-way analysis of variance (ANOVA)

mosquito for comparison purposes. The observed increase in total body protein content of mosquito larvae treated with hypochlorite compounds was quantitatively different to observe the effect of other insecticide group treatments in insects. JinClark et al. (2008) found that using metachlor at $1000 \mathrm{\mu gl}^{-1}$ inhibited protein synthesis in the midge Chironomus tentans. In addition, Sak et al. (2006) revealed that the larvae of Pimpla turionellae had lowest level of protein following treatment with 20 ppm cypermethrin. Also, azadirachtin is known to reduce protein concentration in insects (Arrese et al., 2001; Tufail and Takeda, 2008; Kerkut, 2013).

Total carbohydrate content : Table 2 shows the total body carbohydrate contents of different larval instars of $C$. pipiens exposed to $1 / 10 \mathrm{LC}_{50}$ and $\mathrm{LC}_{50}$ of sodium and calcium hypochlorite. The total body carbohydrate contents of all larval instars significantly increased following treatment with $\mathrm{LC}_{50}$. However, treatment of larvae with $1 / 10 \quad L_{50}$ significantly reduced the total carbohydrate content as compared with control. In addition, treatment of larvae with $1 / 10 L_{50}$ of sodium hypochlorite significantly decreased the total carbohydrate contents as compared with the control. On the other hand, treatment of larvae with $\mathrm{LC}_{50}$ of sodium hypochlorite significantly increased the total body carbohydrate contents as compared with the control values (Fig. 2C). A similar trend was detected when larvae were treated with $1 / 10 L_{50}$ of calcium hypochlorite where total body carbohydrate contents significantly decreased in $1^{\text {st }}, 2^{\text {nd }}, 3^{\text {rd }}$ and $4^{\text {th }}$ larval instars as compared with the control values. Contrarily, when larvae were treated with $\mathrm{LC}_{50}$ of calcium hypochlorite, the total body carbohydrate content values significantly increased for $1^{\text {st }}, 2^{\text {nd }}, 3^{\text {rd }}$ and $4^{\text {th }}$ larval instars as compared with the control values (Fig. 2D).

In that context, mobilization of metabolic reserves in insects respond strikingly to the physiological conditions such as infection, starvation and insecticides (Nowosielski and Patton, 1965; Bitondi and Simoes, 1994; Lorenzon et al., 2004). The haemolymph trehalose levels respond strikingly to the nutritional state (Hansen, 1964; Simpson et al., 2002; Oonincx and Van der Poel, 2011), larval instars (Howden and Kilby, 1960; Kanost et al., 2004), and to metabolic process (Nowosielski and Patton, 1964). Downer, (1979) and Lee and Park (2004) reported that under stress due to disease or other cause, insects hyperglycaemia and hypertrehalosemia in their haemolymph. Similar findings were observed in the present study when C. pipiens larvae exposed to hypochlorite compounds at low sub lethal concentration $\left(\mathrm{LC}_{50}\right)$. Such stress might have triggered the biochemical changes such as glycogenlysis of fat body leading to the increased sugar content 

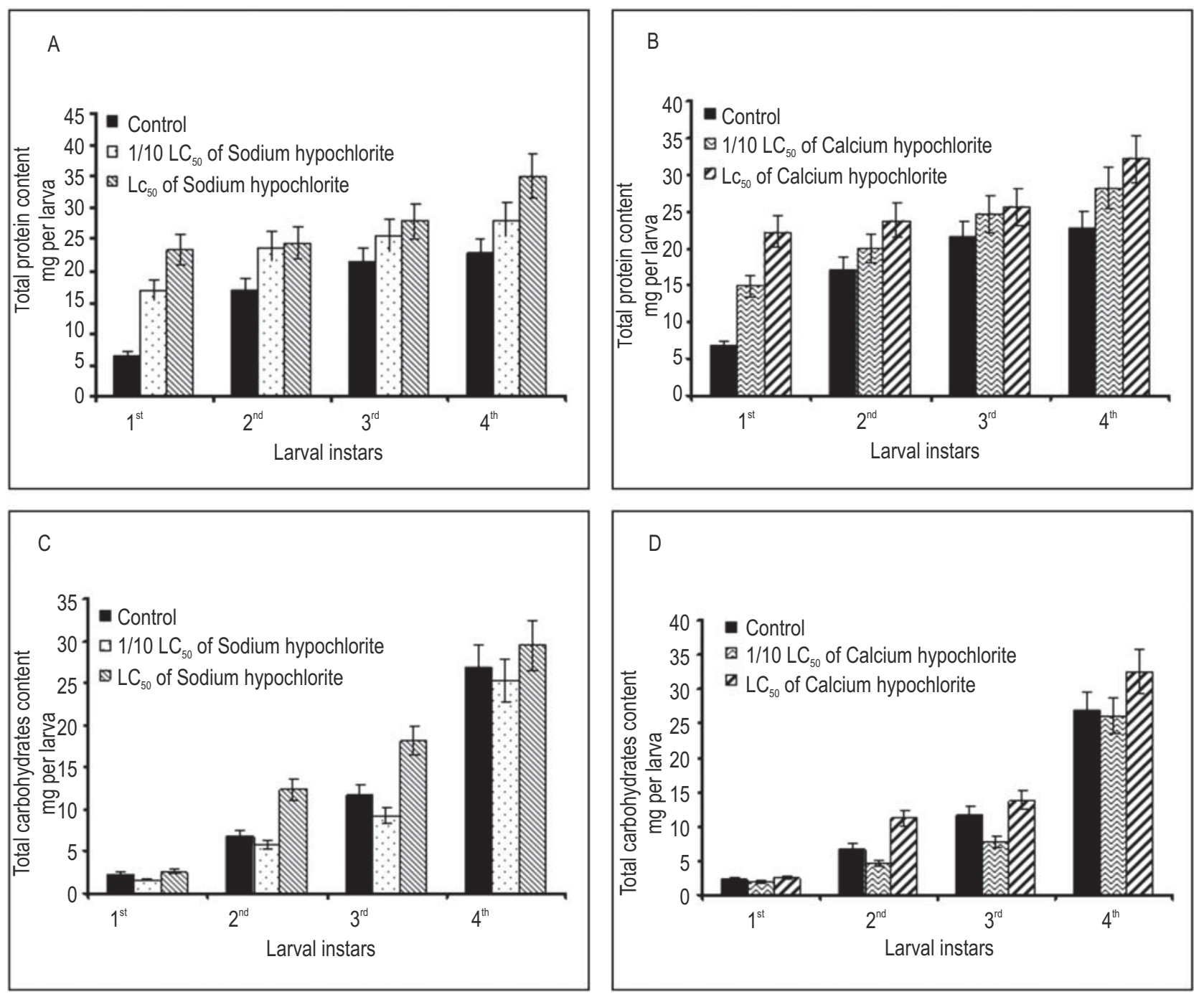

Fig. 2 : Total body protein content of $C$. pipiens four larval instars exposed to $1 / 10 \mathrm{LC}_{50}$ and $\mathrm{LC}_{50}$ of sodium hypochlorite and calcium hypochlorite (A,B); Total body carbohydrate content $(C, D)$ of $C$. pipiens four larval instars exposed to $1 / 10 \mathrm{LC}_{50}$ and $\mathrm{LC}_{50}$ of sodium hypochlorite and calcium hypochlorite

(hyperglycaemia). On the other hand, the decreased carbohydrate content of $C$. pipiens larvae at $1 / 10 L_{50}$ of hypochlorite could be correlated to the antifeedant properties of the compounds which led to starvation under such situations, more sugars might be metabolised to meet the energy expenses of starved larvae.

There are no previous relevant data in literatures to compare sub lethal effects of hypochlorite compounds on larval mosquito biochemical profiling of primary metabolites. However, (Singh, 1986; Isabel et al., 2005) found that bioremethrin treatment of the locust, Locusta migratoria, results in depletion of carbohydrates (hypoglycaemia); and suggested that the depletion of haemolymph carbohydrates might be attributed to the increased utilization in response to the hyper activity caused by the insecticide treatment. Similarly, (Faheem and Khan, 2010; Rashwan, 2013) examined the effects of $L D_{50}, L D_{70}$ and $L D_{90}$ of dimilin, malathion and cypermethrin on the total contents of carbohydrates in the $5^{\text {th }}$ larval instar and adult stage of the lesser cotton leaf worms Spodoptera exigua treated as $4^{\text {th }}$ instar larvae. The authors came to a conclusion that the percentage decreased in the total carbohydrate contents of tested larvae, and adults of both sexes were dose-dependent. In another study Omar et al. (2005) recorded a general decrease in the amount of carbohydrates in Dipel and 2X-treated Galleria mellonella larvae. In addition, Senthilkumar et al. (2009) found that Anopheles stephensi (Liston) larvae treated with eleven commonly available medicinal plants showed decreased level of carbohydrates.

Total lipid content : Table 3 shows total lipid contents of four larval instars of $C$. pipiens exposed to $1 / 10 L_{50}$ and $L_{50}$ of sodium and calcium hypochlorite. Generally, treatment of larvae with sub lethal concentrations of both hypochlorite 

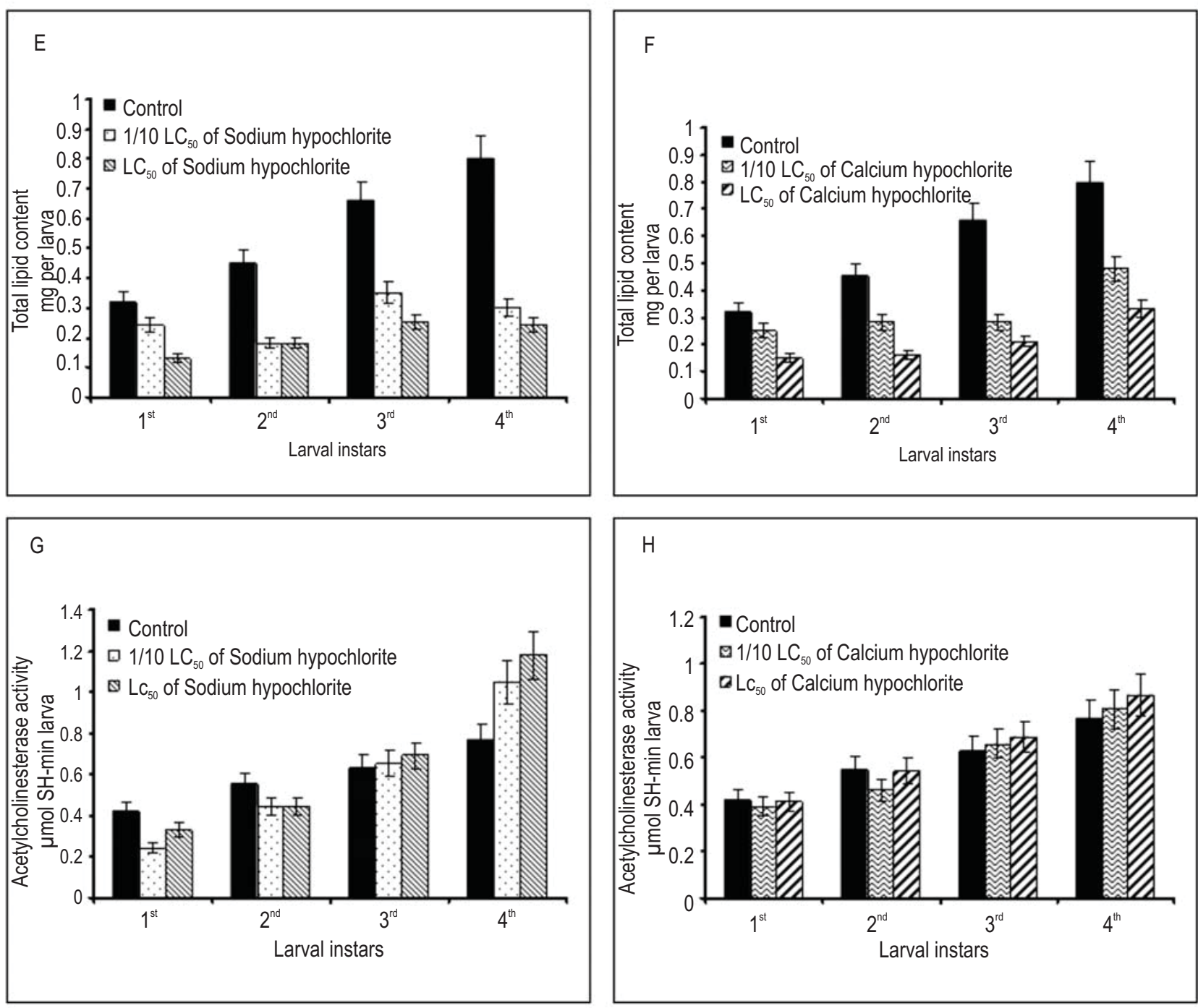

$\mathrm{H}$

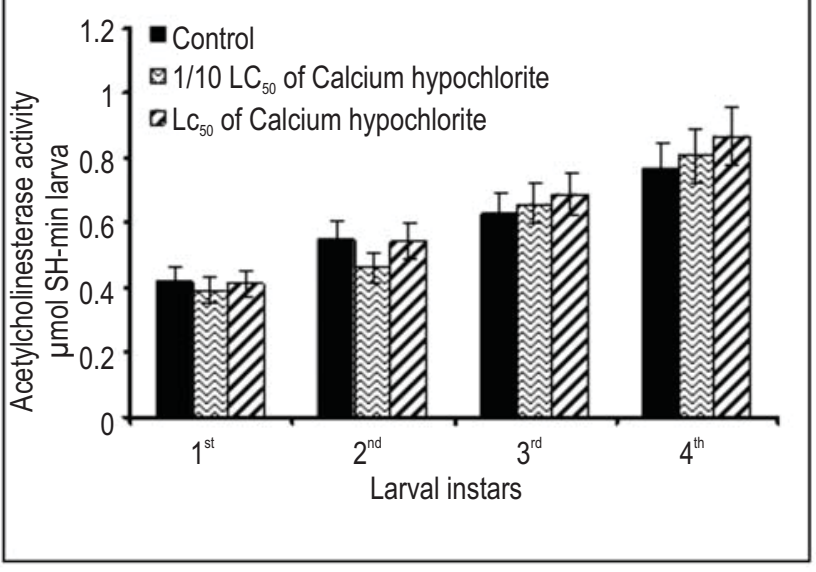

Fig. 2 : Total body lipid contents (E, F) and Acetylcholinesterase activity $(G, H)$ of C.pipiens four larval instars exposed to $1 / 10 \mathrm{LC}_{50}$ and $L C_{50}$ of sodium hypochlorite and calcium hypochlorite

induced significant reduction in total lipid contents as compared to control. Treatment of larvae with $1 / 10 \mathrm{LC}_{50}$ of sodium hypochlorite significantly decreased the total lipid contents of $1^{\text {st }}, 2^{\text {nd }}, 3^{\text {td }}$ and $4^{\text {th }}$ larval instars as compared with control. Meanwhile, when larvae were treated with $\mathrm{LC}_{50}$ of sodium hypochlorite, the values of total body lipid contents significantly decreased for $1^{\text {st }}, 2^{\text {nd }}, 3^{\text {rd }}$ and $4^{\text {th }}$ larval instars as compared with the control values (Fig. 2E).

Similarly, when the larvae were treated with $1 / 10 \mathrm{LC}_{50}$ of calcium hypochlorite, the total body lipid contents significantly decreased as compared with the control. In addition, when the larvae were treated with $\mathrm{LC}_{50}$ of calcium hypochlorite the values significantly decreased as compared with the control (Fig. 2F). This might be attributed to the physiological stress conditions induced by the hypochlorite compounds, extended larval period of treated insects, blocked food ingestion and the fat reserves might have been utilized for energy generation during the extended larval periods and interference of hypochlorite with the adipokinetic hormone that control lipid synthesis leading to reduced lipid profiles. In this sense, hypochlorite compounds can be classified with those chemicals that are known to inhibit energy production in insects. Similar poisoning syndrome of insecticides on lipid content of insects has been reported in several insects. Senthilkumar et al. (2009) found that Anopheles stephensi larvae treated with medicinal plant extracts showed decreased level of lipids. In addition, Lohar and Wright (1993) verified lipid depletion in haemolymph, fat body and oocytes in Tenebrio molito exposed to parathion. They suggested that depletion of lipid might result from the effect of parathion on the adipokinetic hormone that controls lipid metabolism. Similarly, the total lipid contents 
Table 3 : Total body lipid contents of $C$. pipiens larval instars exposed to $1 / 10 \mathrm{LC}_{50}$ and $\mathrm{LC}_{50}$ of sodium and calcium hypochlorite

\begin{tabular}{|c|c|c|c|c|c|}
\hline \multirow{3}{*}{$\begin{array}{l}\text { Larval } \\
\text { instars }\end{array}$} & \multicolumn{5}{|c|}{ Total body lipid contents } \\
\hline & \multirow[t]{2}{*}{ Control } & \multicolumn{2}{|c|}{ Sodium hypochlorite } & \multicolumn{2}{|c|}{ Calcium hypochlorite } \\
\hline & & $1 / 10 \mathrm{LC}_{50}$ & $\mathrm{LC}_{50}$ & $1 / 10$ LC $_{50}$ & $\mathrm{LC}_{50}$ \\
\hline $1^{\text {st }}$ & $0.32 \pm 0.08$ & $0.24 \pm 0.08^{*}$ & $0.13 \pm 0.06^{*}$ & $0.25 \pm 0.03^{*}$ & $0.15 \pm 0.004^{*}$ \\
\hline $2^{\text {nd }}$ & $0.45 \pm 0.14$ & $0.18 \pm 0.05^{*}$ & $0.18 \pm 0.05^{*}$ & $0.28 \pm 0.07^{*}$ & $0.16 \pm 0.02^{*}$ \\
\hline $3^{\text {rd }}$ & $0.66 \pm 0.07$ & $0.35 \pm 0.08^{*}$ & $0.25 \pm 0.07^{*}$ & $0.28 \pm 0.08^{*}$ & $0.21 \pm 0.05^{*}$ \\
\hline $4^{\text {th }}$ & $0.80 \pm 0.10$ & $0.30 \pm 0.07^{*}$ & $0.24 \pm 0.07^{*}$ & $0.48 \pm 0.07^{*}$ & $0.33 \pm 0.10^{*}$ \\
\hline
\end{tabular}

Values are mean of six replicates $\pm S D$; *Significant at $\mathrm{P} \leq 0.001$ using multi-way analysis of variance (ANOVA)

Table 4 : Effect of $1 / 10 \mathrm{LC}_{50}$ and $\mathrm{LC}_{50}$ of sodium and calcium hypochlorite on the activities of acetylcholinesterase ( $\mu$ mol SH per min per larva) in the four developmental stages of $C$. pipiens

\begin{tabular}{|c|c|c|c|c|c|}
\hline \multirow{3}{*}{$\begin{array}{l}\text { Larval } \\
\text { instars }\end{array}$} & \multicolumn{5}{|c|}{ Enzyme activity } \\
\hline & \multirow[t]{2}{*}{ Control } & \multicolumn{2}{|c|}{ Sodium hypochlorite } & \multicolumn{2}{|c|}{ Calcium hypochlorite } \\
\hline & & $1 / 10 L_{50}$ & $\mathrm{LC}_{50}$ & $1 / 10 L_{50}$ & $\mathrm{LC}_{50}$ \\
\hline $1^{\text {st }}$ & $0.42 \pm 0.03$ & $0.24 \pm 0.04^{*}$ & $0.33 \pm 0.06^{*}$ & $0.39 \pm 0.03^{\text {in }}$ & $0.41 \pm 0.02^{\text {in }}$ \\
\hline $2^{\text {nd }}$ & $0.55 \pm 0.05$ & $0.44 \pm 0.03^{*}$ & $0.44 \pm 0.06^{*}$ & $0.46 \pm 0.04^{*}$ & $0.54 \pm 0.05^{*}$ \\
\hline $3^{\text {rd }}$ & $0.63 \pm 0.06$ & $0.65 \pm 0.02^{\text {in }}$ & $0.69 \pm 0.07^{*}$ & $0.66 \pm 0.07^{\text {in }}$ & $0.69 \pm 0.08^{*}$ \\
\hline $4^{\text {th }}$ & $0.77 \pm 0.11$ & $1.05 \pm 0.11^{*}$ & $1.18 \pm 0.04^{*}$ & $0.81 \pm 0.08^{*}$ & $0.874 \pm 0.1^{*}$ \\
\hline
\end{tabular}

Values are mean of six replicates $\pm S D$; ${ }^{*}$ Significant at $P \leq 0.01$, in insignificant using multi-way analysis of variance (ANOVA)

decreased in Bacillust huriengensis. var. kurstaki-treated Galleria mellonella larvae (Omar et al., 2005). Sub lethal doses of crpermethrin decreased the level of lipids in all stages and sexes of wasp Pimpla turionellae (L.) compared to control (Sak et al., 2006). The bioinsecticide, Dipel $2 X$, significantly decreased the total lipid content in Spodoptera littoralis (Abuldahab et al., 2011).

Acetylcholinesterase activity : Table 4 shows the acetylcholinesterase activity of different larval instars of $C$. pipiens exposed to $1 / 10 L_{50}$ and $L_{50}$ of sodium and calcium hypochlorite. In general, the acetylcholinesterase activity significantly decreased in the treated first and second larval instars. Meanwhile a significant increase in enzyme activity was observed in the treated third and fourth larval instars as compared with the control.

The acetylcholinesterase activities of larvae treated with $1 / 10$ LC $_{50}$ of sodium hypochlorite showed a significant decrease in $1^{\text {st }}$ and $2^{\text {nd }}$ larval instars. On the other hand, significant increase in enzyme activity was observed in treated $3^{\text {rd }}$ and $4^{\text {th }}$ larval instars as compared with the control. A similar trend was observed when the larvae were treated with $\mathrm{LC}_{50}$ of sodium hypochlorite. The acetylcholinesterase enzyme activity significantly decreased in $1^{\text {st }}$ and $2^{\text {nd }}$ larval as compared with the control enzyme activity. Meanwhile significant increase of enzyme activities was detected in $3^{\text {rd }}$ and $4^{\text {th }}$ larval instars compared with the control (Fig. 2G).
Similarly, larvae exposed to $1 / 10 \mathrm{LC}_{50}$ of calcium hypochlorite showed significant decrease in acetylcholinesterase activity for $1^{\text {st }}$ and $2^{\text {nd }}$ larval instars, while a significant increase in enzyme activity was detected for $3^{\text {rd }}$ and $4^{\text {th }}$ larval as compared with the control. Meanwhile, the enzyme activity significantly decreased in $1^{\text {st }}$ and $2^{\text {nd }}$ larval instars when larvae were treated with $L_{50}$ of calcium hypochlorite, while a significant increase in enzyme activity was observed in $3^{\text {rd }}$ and $4^{\text {th }}$ larval instars as compared with the control (Fig. 2H).

Mosquito monitoring is facing many important and timely stump because of the rapid development of pesticide resistance and ecological troubles. Botanical extracts are used as mosquitocidal and may offer effective and ecofriendly tools against Culicidae vectors recently. Balakrishnan et al. (2017) reported that the separated actinobacteria were investigated as larvicidal against Aedes aegypti and Anopheles stephensi mosquitoes, while Zhang et al. (2017) found that Bacillus thuringiensis showed activity against mosquito larvae. Treatment of $C$. pipiens larvae with sub lethal concentrations of hypochlorite resulted in degeneration of cell structure of the alimentary canal. This new insecticide is suggested as a useful addition to the rather dwindling arsenal of mosquito control in Egypt. However, further investigations, especially field studies, on non-target aquatic 
organisms are needed to further confirm the target and nontarget effects of insecticides.

\section{Acknowledgments}

Authors are grateful to the Director and staff of Zoology Department, Faculty of Science, Tanta University. In particular, we thank Dr. Wesam S Meshrif, Dr. Samar E Elkholy and Dr. Iman M. El-Husseiny of the Entomology Unit for their help and support during the study.

\section{References}

Abuldahab, F., Y. Abozinadah and S. Al-Haiqi: Impact of Bacillus thuringiensis exotoxin to some biochemical aspects of Musca domestica (Diptera : Muscidae). African J. Bacteriol. Res., 3, 92100 (2011).

Al-Mekhlafi, F.A., N. Abutaha, A.M.A. Mashaly, F.A. Nasr, K.E. Ibrahim and M.A. Wadaan: Biological activity of Xanthium strumarium seed extracts on different cancer cell lines and Aedes caspius, Culex pipiens (Diptera : Culicidae). Saudi J. Biological Sci., 24, 817-821 (2017).

Al-Sharkawi, I.: Chlorinated lime pockets : A model proposed for the control of Schistosoma mansoni transmission in irrigation streams and ditches in Egypt. J. Egypt. German Soc. Zool., 23, 209-236 (1997).

Andersen, L.K. and M.D. Davis : Climate change and the epidemiology of selected tick-borne and mosquito-borne diseases: Update from the International Society of Dermatology climate change task force. Int. J. Dermatol., 56, 252-259 (2016).

Arrese, E.L., L.E. Canavoso, Z.E. Jouni, J.E. Pennington, K. Tsuchida and M.A. Wells: Lipid storage and mobilization in insects: Current status and future directions. Insect Biochem. Mole. Biol., 31, 7-17 (2001).

Balakrishnan, S., P. Santhanam and M. Srinivasan : Larvicidal potency of marine actinobacteria isolated from mangrove environment against Aedes aegypti and Anopheles stephensi. J. Parasitic Dis., 41, 387-394 (2017).

Barrera, R., M. Amador and G.G. Clark: The use of household bleach to control Aedes aegypti. J. American Mosquito Control Asso., 20, 444-448 (2004).

Benelli, G., R. Pavela, A. Canale, K. Cianfaglione, G. Ciaschetti, F. Conti, M. Nicoletti, S. Senthil-Nathan, H. Mehlhorn and F. Maggi: Acute larvicidal toxicity of five essential oils (Pinus nigra, Hyssopus officinalis, Satureja montana, Aloysia citrodora and Pelargonium graveolens) against the filariasis vector Culex quinquefasciatus : Synergistic and antagonistic effects. Parasitol. Int., 66, 166-171 (2017).

Bitondi, M. and Z. Simoes: Variation in the haemolymph protein composition of confined Apis mellifera and partial restoration of Vitellogenin titre by juvenile hormone analogue treatment. J. Hym. Res, 3, 107-117 (1994).

Brustolin, M., S. Talavera, A. Nunez, C. Santamaria, R. Rivas, N. Pujol, M. Valle, M. Verdun, A. Brun, N. Pages and N. Busquets: Rift valley fever virus and European mosquitoes: Vector competence of Culex pipiens and Stegomyia albopicta. Medi. Veter. Entomol., 31, 365-372 (2017).

Cabrerizo Ballesteros, S., M. de Barrio, M.L. Baeza and M. Rubio Sotes: Allergy to chironomid larvae (red migde larvae) in non professional handlers of fish food. J. Investig. Allergol. Clin. Immunol., 16, 63-68 (2006).
Chang, K.S., H.C. Kim, T.A. Klein and Y.R. Ju : Insecticide resistance and cytochrome-p450 activation in unfed and blood-fed laboratory and field populations of Culex pipiens pallens. J. Pest Sci., 90, 759-771 (2017).

David, M.R., L.M. Santos, A.C. Vicente and R. Maciel-de-Freitas: Effects of environment, dietary regime and ageing on the dengue vector microbiota : Evidence of a core microbiota throughout Aedes aegyptilifespan. Mem. Inst. Oswaldo. Cruz., 111, 577-587 (2016).

Djogbénou, L., V. Noel and P. Agnew: Costs of insensitive acetylcholinesterase insecticide resistance for the malaria vector Anopheles gambiae homozygous for the g119s mutation. Malaria J., $9,1(2010)$.

Downer, R.: Induction of hypertrehalosemia by excitation in Periplaneta americana. J. Insect Physiol., 25, 59-63 (1979).

Ellman, G.L., K.D. Courtney, V. Andres and R.M. Featherstone: A new and rapid colorimetric determination of acetylcholinesterase activity. Biochemical Pharmacol., 7, 88-95 (1961).

Faheem, M. and M.F. Khan: Toxicity of imidacloprid (nicotinoid) against earthworm, Pheretima posthuma with reference to its effects on protein. J. Basic Appl. Sci., 6, 55-62 (2010).

Ferreira, C.P., S.P. Lyra, F. Azevedo, D. Greenhalgh and E. Massad : Modelling the impact of the long-term use of insecticide-treated bed nets on Anopheles mosquito biting time. Malar. J., 16, 373 (2017).

Fouad, H., L. Hongjie, D. Hosni, J. Wei, G. Abbas, H. Ga'al and M. Jianchu : Controlling Aedes albopictus and Culex pipiens pallens using silver nanoparticles synthesized from aqueous extract of Cassia fistula fruit pulp and its mode of action. Artificial cells, Nanomed. biotechnol., 25, 1-10 (2017).

Frings, C.S., T.W. Fendley, R.T. Dunn and C.A. Queen: Improved determination of total serum lipids by the sulfo-phospho-vanillin reaction. Clinical Chemistry, 18, 673-674 (1972).

Hansen, O.: Effect of diet on the amount and composition of locust blood carbohydrates. Biochemical J., 92, 333 (1964).

Harbach, R.E.: The mosquitoes of the subgenus Culex in southwestern Asia and Egypt (Diptera: Culicidae). Contributions of the American Entomological Institute, Vol. 24, (1988).

Hayat, N., S. Ahmad, N. Shamaan, M. Sabullah, M. Shukor, M. Syed, A. Khalid, K. Khalil and F. Dahalan: Characterisation of cholinesterase from kidney tissue of asian seabass (Lates calcarifer) and its inhibition in presence of metal ions. J. Enviro. Biol., 38, 383 (2017).

Howden, G. and B. Kilby : Biochemical studies on insect haemolymph-I. Variations in reducing power with age and the effect of diet. $J$. Insect Physiol., 4, 258-269 (1960).

Huang, W.K., J.H. Sun, J.K. Cui, G.F. Wang, L.A. Kong, H. Peng, S.L. Chen and D.L. Peng: Efficacy evaluation of fungus Syncephalastrum racemosum and nematicide avermectin against the root-knot nematode Meloidogyne incognita on cucumber. PLoS One, 9, e89717 (2014).

Isabel, G., J.-R. Martin, S. Chidami, J.A. Veenstra and P. Rosay: Akhproducing neuroendocrine cell ablation decreases trehalose and induces behavioral changes in Drosophila. American J. Physiol.Regula. Integ. Compar. Physiol., 288, R531-R538 (2005).

Jin-Clark, Y., T.D. Anderson and K.Y. Zhu : Effect of alachlor and metolachlor on toxicity of chlorpyrifos and major detoxification enzymes in the aquatic midge, Chironomus tentans (diptera : Chironomidae). Arc. Environ. Contam. Toxicol., 54, 645-652 (2008).

Kady, G., N.H. Kamel, Y.Y. Mosleh and I.M. Bahght: Comparative toxicity of two bio-insecticides (spinotoram and vertemic) compared with methomyl against Culex pipiens and Anopheles multicolor. World J. Agricul. Sci., 4, 198-205 (2005).

Kanost, M.R., H. Jiang and X.Q. Yu : Innate immune responses of a 
lepidopteran insect, Manduca sexta. Immunol. Revi., 198, 97105 (2004).

Kerkut, G.A.: Biochemistry. Vol. 10, Elsevier (2013).

Kim, S.I. and Y.J. Ahn: Larvicidal activity of lignans and alkaloid identified in Zanthoxylum piperitum bark toward insecticide-susceptible and wild Culex pipiens pallens and Aedes aegypti. Parasites and Vectors, 10, 221 (2017).

Korte, R.L., G. Fontes, S. Camargo Jde, E.M. Rocha, E.A. Araujo, M.Z. Oliveira, R.V. Santos and L.M. Camargo : Survey of bancroftian filariasis infection in humans and Culex mosquitoes in the western Brazilian Amazon region : Implications for transmission and control. Rev. Soc. Bras. Med. Trop., 46, 214-220 (2013).

Labbe, P., C. Berticat, A. Berthomieu, S. Unal, C. Bernard, M. Weill and T. Lenormand: Forty years of erratic insecticide resistance evolution in the mosquito Culex pipiens. PLoS Genet., 3, e205 (2007).

Labbé, P., N. Sidos, M. Raymond and T. Lenormand : Resistance gene replacement in the mosquito Culex pipiens : Fitness estimation from long-term cline series. Genetics, 182, 303-312 (2009).

Lee, G. and J.H. Park : Hemolymph sugar homeostasis and starvationinduced hyperactivity affected by genetic manipulations of the adipokinetic hormone-encoding gene in Drosophila melanogaster. Genetics, 167, 311-323 (2004).

Lenormand, T. and M. Raymond : Analysis of clines with variable selection and variable migration. American Naturalist, 155, 70-82 (2000).

Lohar, M. and D. Wright: Changes in the lipid content in haemolymph, fat body and oocytes of malathion treated Tenebrio molitor l. Adult females. Pak. J. Zool., 25, 57-57 (1993).

Lorenzon, S., P. Edomi, P.G. Giulianini, R. Mettulio and E.A. Ferrero: Variation of crustacean hyperglycemic hormone (chh) level in the eyestalk and haemolymph of the shrimp Palaemon elegans following stress. J. Exp. Biol., 207, 4205-4213 (2004).

Lowry, O.H., N.J. Rosebrough, A.L. Farr and R.J. Randall: Protein measurement with the folin phenol reagent. J. Biol. Chem., 193, 265-275 (1951).

Mariappan, T., A. Selvam, V. Rajamannar and N. Arunachalam: Susceptibility of dengue/ chikungunya vector, Aedes aegypti against carbamate, organochlorine, organophosphate and pyrethroid insecticides. J. Environ. Biol., 38, 251-255 (2017).

Matsuda, K., S.D. Buckingham, D. Kleier, J.J. Rauh, M. Grauso and D.B. Sattelle: Neonicotinoids : Insecticides acting on insect nicotinic acetylcholine receptors. Trends Pharmacol. Sci., 22, 573-580 (2001).

Mitchell, S.N., E.G. Kakani, A. South, P.I. Howell, R.M. Waterhouse and F. Catteruccia : Mosquito biology. Evolution of sexual traits influencing vectorial capacity in anopheline mosquitoes. Science, 347, 985-988 (2015).

Mutero, A., M. Pralavorio, J.-M. Bride and D. Fournier : Resistanceassociated point mutations in insecticide-insensitive acetylcholinesterase. Proce. National Academy Sci, 91, 59225926 (1994)

Neoliya, N., D. Singh and R. Sangwan : Azadirachtin-based insecticides induce alteration in Helicoverpa armigera hub. Head polypeptides. Curr. Sci., 92, 94-99 (2007).

Nowosielski, J.W. and R.L. Patton : Variation in the haemolymph proteins, amino acids and lipid levels in adult house crickets, Acheta domesticus (I.) of different ages. J. Insect Physiol., 11, 263270 (1964).

Nowosielski, J.W. and R.L. Patton : Variation in the haemolymph protein, amino acid and lipid levels in adult house crickets, Acheta domesticus I., of different ages. J. Insect Physiol., 11, 263-270 (1965).
Omar, N., M. El-Husseini and M. El-Bishry : Carbohydrate pattern in larvae of the wax moth, galleria mellonella I. Infected with Bacillus thuringiensis kurstaki. Egyptian J. Biolo. Pest Cont., 15, 77-79 (2005).

Omar, N., A. Mousa, M. El-Husseini and M. El-Bishry : Changes in lipid contents due to infection with Bacillus thuringiensis kurstaki in larvae of the greater wax moth, Galleria mellonella I. (Lepidoptera: Galleridae). Egyptian J. Biol.I Pest Cont., 15, 41-44 (2005).

Oonincx, D. and A. Van der Poel : Effects of diet on the chemical composition of migratory locusts (Locusta migratoria). Zoo. Biol., 30, 9-16 (2011).

$\mathrm{Pu}, \mathrm{X}$., Y. Yang, S. Wu and Y. Wu : Characterisation of abamectin resistance in a field evolved multiresistant population of Plutella xylostella. Pest Manag. Sci., 66, 371-378 (2010).

Rashwan, M.H. : Biochemical impacts of rynaxypyr (coragen) and spinetoram (radiant) on Spodoptera littoralis (boisd.). Nature and Sci., 11, 40-47 (2013).

Raymond, M., C. Berticat, M. Weill, N. Pasteur and C. Chevillon: Insecticide resistance in the mosquito Culex pipiens: What have we learned about adaptation In : In: Microevolution Rate, Pattern, Process. Contemporary Issues in Genetics and Evolution (Eds.: A.P. Hendry and M.T. Kinnison). Vol 8, Springer, pp. 287-296 (2001).

Roberts, D.R. and R.G. Andre : Insecticide resistance issues in vectorborne disease control. Amer. J. Tropic. Medi. Hygiene, 50, 21-34 (1993).

Rozsypal, J., V. Koštál, P. Berková, H. Zahradníčková and P. Šimek: Seasonal changes in the composition of storage and membrane lipids in overwintering larvae of the codling moth, Cydia pomonella. J. Thermal Biol., 45, 124-133 (2014).

Sak, O., F. Uckan and E. Ergin: Effects of cypermethrin on total body weight, glycogen, protein and lipid contents of Pimpla turionellae (I.)(Hymenoptera: Ichneumonidae). Belgian J. Zool., 136, 53 (2006).

Senthilkumar, N., P. Varma and G. Gurusubramanian: Larvicidal and adulticidal activities of some medicinal plants against the malarial vector, Anopheles stephensi (liston). Parasitol. Res., 104, 237-244 (2009).

Simpson, S., D. Raubenheimer, S. Behmer, A. Whitworth and G. Wright: A comparison of nutritional regulation in solitarious-and gregarious-phase nymphs of the desert locust Schistocerca gregaria. J. Exp. Biol., 205, 121-129 (2002).

Singh, G.J.P.: Hemolymph carbohydrate and lipid mobilization in Locusta migratoria in relation to the progress of poisoning following bioresmethrin treatment. Pesticide Biochemi. Physiol., 25, 264269 (1986).

Singh, N. and R. Sinha : Carbohydrate, lipid and protein in the developmental stages of Sitophilus oryzae and $S$. granarius (Coleoptera : Curculionidae). Ann. Entomol. Soc. Amer., 70, 107111 (1977).

Southgate, B.A.: Bancroftian filariasis in Egypt. Trop. Dis .Bull., 76, 10451068 (1979).

Tangena, J.A., P. Thammavong, A.L. Wilson, P.T. Brey and S.W. Lindsay: Risk and control of mosquito-borne diseases in Southeast Asian rubber plantations. Trends Parasitol., 32, 402-415(2016).

Tufail, M. and M. Takeda : Molecular characteristics of insect vitellogenins. J. Insect Physiol., 54, 1447-1458 (2008).

Yadouleton, A.W., G. Padonou, A. Asidi, N. Moiroux, S. Bio-Banganna, V. Corbel, R. N'guessan, D. Gbenou, I. Yacoubou and K. Gazard: Insecticide resistance status in Anopheles gambiae in Southern Benin. Malaria J., 9, 1 (2010).

Zhang, Q., G. Hua and M.J. Adang: Effects and mechanisms of Bacillus thuringiensis crystal toxins for mosquito larvae. Insect Sci., 24, 714-729 (2017). 